\title{
Lusisersily
}

\section{Community participation in Jamaican conservation projects}

Lundy, P. (1999). Community participation in Jamaican conservation projects. Community Development Journal, 34(2), 122-132.

Link to publication record in Ulster University Research Portal

Published in:

Community Development Journal

Publication Status:

Published (in print/issue): 01/01/1999

\section{Document Version}

Publisher's PDF, also known as Version of record

\section{General rights}

Copyright for the publications made accessible via Ulster University's Research Portal is retained by the author(s) and / or other copyright owners and it is a condition of accessing these publications that users recognise and abide by the legal requirements associated with these rights.

\section{Take down policy}

The Research Portal is Ulster University's institutional repository that provides access to Ulster's research outputs. Every effort has been made to ensure that content in the Research Portal does not infringe any person's rights, or applicable UK laws. If you discover content in the Research Portal that you believe breaches copyright or violates any law, please contact pure-support@ulster.ac.uk. 


\title{
Community
}

Patricia Lundy

participation in

Jamaican

conservation

projects

\begin{abstract}
International aid for conservation currently favours assisting projects promoting local-level solutions derived from 'community' initiatives. Nongovernmental organisations (NGOs) are fast becoming the preferred infrastructure through which such funding is channelled. This paper examines the role of environmental NGOs in 'community-based' conservation projects in Jamaica. Concepts of participation, assumptions about 'community', and issues of representation are explored. The central argument advanced in the paper is that, Jamaican environmental groups represent a narrow constituency. Those more likely to be effected by environmental degradation, the poor and marginalised, appear to be the least likely to be involved in environmental NGOs and 'community-based' conservation projects. The paper concludes that international donors, and practitioners, should critically address such weaknesses in projects and endeavour to understand the impediments to participation.
\end{abstract}

\section{Introduction}

The last decade has seen a huge increase in the numbers of non-governmental organisations (NGOs) in the South (Edwards and Hulme, 1995). In Jamaica, recent research has indicated a significant growth in the number of environmental NGOs ${ }^{1}$ and the size of their membership (see Lundy, 1998, for an overview). During the period 1988 to 1995 alone, at least 28 environmental groups were formed at the national, parish and 'community' level. The groups are based both in rural and in urban areas and their supporters and activists are often drawn from a common locality. A number of the 'community-based' environmental groups are relatively small and have as few as a dozen or so members. There are, however, much larger national and parish based groups which claim to have several hundred members.

Using empirical data from research carried out in Jamaica, this paper examines the activities of environmental NGOs (ENGOs) with regard to 'community-based' conservation projects. The paper begins with a brief

1. The term NGOs is used in this paper to cover all forms of non-profit organisations i.e. intermediary organisations, grassroots organisations, community-based organisations. 
discussion about the methods used. This is followed by an examination of key issues which pervade current conservation policy and practice. This includes, an analysis of concepts of participation and assumptions about 'community' espoused in conservation policy. The paper goes on to consider how Jamaican ENGOs have put conservation policy into practice. Using a variety of data sources, including a case study of the Portland Environmental Protection Association (PEPA), the paper examines a number of important issues concerning ENGO activities. In particular issues of representation and the promotion of participation are discussed. A central argument advanced is that, despite recent acclaim, NGOs have certain limitations that must be acknowledged.

\section{Methods}

The paper draws upon data gathered from research carried out in Jamaica between June and September 1995. A total of 36 environmental groups were identified in parishes throughout Jamaica. In-depth semi-structured interviews were carried out with representatives from 23 of the 36 groups and a questionnaire was distributed. A total of 56 formal interviews were conducted. The sample reflects the different types of groups operating at the 'community', parish, and national level. A number of committee meetings, conferences, workshops and seminars held by the environmental groups were attended. An analysis of minutes of meetings, campaign literature, membership records, newsletters, annual reports, constitutions, and other relevant material of the organisations was undertaken. The data gathered from the above sources shed light on the nature and activities of Jamaican ENGOs.

In addition to interviews with group members, a small number of interviews were carried out with representatives of international organisations involved in funding environmental groups and projects. Interviews were carried out with senior staff in The Environmental Foundation of Jamaica (EFJ), the Green Fund and USAID. An analysis of donor mission statements, written policies, annual reports, funding guidelines, records of funding allocated, evaluation procedures, Articles of Association, and other relevant material was undertaken. A number of projects funded by EFJ, the Green Fund and USAID were also visited. The data gathered from these sources provide insights into donor conservation policy, strategy and practice.

\section{Conservation policy: themes and controversies}

Donor conservation policy has been influenced by the United Nations Conference on Environment and Development (UNCED). The consensus in the wake of the UNCED was that conservation should be based on local-level solutions derived from community initiatives (Leach, 1997, p. 5). This is 
reflected in statements of intent on global environmental problems issue following the 1992 Earth Summit, including Agenda 21. These statements strongly advocated a combination of government decentralisation, devolution to local communities of responsibility for natural resources held as commons, and community participation (Leach, 1997, p. 5). Such approaches are evident in the policies and programmes of Jamaican donors. The Environmental Foundation of Jamaica (EFJ) states that it will, 'promote and sponsor activities and programmes undertaken by NGOs and community groups ... which involve local community initiatives that promote conservation and sustainable use of the environment' (EFJ, 1995b). The Canada/ Jamaica Green Fund, funded by the Canadian International Development Agency, states that priority will be given to, 'community based initiatives which will contribute to the sound management and conservation of Jamaica's natural resources' (Green Fund, 1995a). In sum, community-based conservation, implemented through NGOs, has become the orthodoxy in the 1990 s, and is now espoused by international donors, national governments and NGOs. The following sections will critically examine key aspects of community-based conservation policy. These include, the role of NGOs, assumptions about community and participation. The paper will then move on to discuss how Jamaican ENGOs have attempted to put policy into practice.

\section{NGOs: the 'magic bullet'?}

As reflected in recent policy initiatives, NGOs have been given a lead role in 'community-based' conservation. NGOs have acquired the reputation that their participatory and less bureaucratised approaches allows them to meet the needs of people with greater efficiency and at less cost (Rahnema, 1992, p. 119). Others have argued that NGOs are better placed for the task of fostering popular participation which includes articulating the needs of the poorest and most vulnerable groups (Clark, 1997, p. 44). However, despite these positive trends, NGO performance and their contribution to development has recently raised a number of criticisms. Recent research has indicated that NGOs do not perform as effectively as had been assumed in terms of poverty-reach, cost-effectiveness, sustainability and popular participation (including gender) (see, for example, Bebbington and Thiele, 1993; Carroll, 1992; Edwards and Hulme, 1995; Riddell and Robinson, 1992; Vivian, 1994). As Vivian (1994) cynically puts it, official agencies often see NGOs as a 'magic bullet' which can be fired off in any direction and, though often without very much evidence, will still find its target.

\section{Community participation}

Today most international organisations, foreign donors, governments and NGOs regard community participation as an essential dimension of development strategies. Indeed failure to emphasise a participatory approach in a project proposal would probably spell its doom and rejection by funders. As 
the following sample of quotes from policy documents and funding guidelines indicate, many donors supporting conservation projects in Jamaica emphasise community participation as priority. The EFJ states that it will give priority to projects that, 'involve communities in their planning and execution' (EFJ, 1995a; my italics). Applicants are cautioned that they must, 'demonstrate community participation and/or community sensitivity in project design and implementation; that there should be evidence that the communities affected by the project endorse and support it' (EFJ, 1995b; my italics). The Canada Green Fund programme, entitled 'Community Based Initiatives In Support of the Process of Sustainable Development in Jamaica', advocates similar funding criteria. It states, 'project proposals must clearly demonstrate the degree to which there is community support and commitment to the proposed project' (Green Fund, 1995b; my italics).

However, participation is one of those contentious words like 'community' which means everything and nothing. There is little agreement about its definition (Croft and Beresford, 1992). Cernea (1985, p. 10) suggests it is, 'empowering people to mobilise their own capacities, be social actors rather than passive subjects, manage the resources, make decisions, and control the activities that affect their lives'. However, some have come to see participation as an elusive concept which is more myth than reality in development projects and have cast doubt over whether it can actually be achieved (Crenea, 1985; Rahnema, 1992). An examination of the relevant conservation literature reveals that unambiguous examples of successful participation are rare. Yet, despite its unproved track record, and ambiguity over its meaning, donors continue to espouse the virtues of participation. To complicate matters further, few donors specify exactly what they mean by participation and how it can be achieved. As I will demonstrate shortly, participation can mean different things to different people.

\section{Assumptions about community}

Obstacles to community participation are common to many development projects. However, a central flaw in many community participatory projects is their mistaken notion about 'community' (Leach et al., 1997). A similar criticism has been made of rural development policy in Ireland (see Shortall, 1994). Underlying today's community-based sustainable development literature is the notion that communities are homogenous entities. Based on these assumptions, the underlying presumption is that 'the community' is capable of acting collectively towards common environmental interests. Social consensus and solidarity is assumed.

Social scientific work has fundamentally questioned many of these assumptions about 'community'. Such work points out that the word 'community' is an ambiguous and elusive concept; it has no single and fixed meanings; it is not a homogenous and harmonious entity (see, for example, Cohen, 1985; Moore, 1993). In addition, social scientific work has highlighted the ways that 
gender, caste, wealth, age, origins, and other aspects of social identity divide and cross-cut so-called 'community' boundaries. This work emphasises how diverse and often conflicting values and resource priorities - rather than shared beliefs and interests - pervade social life and may be struggled and bargained over (Leach et al., 1997, pp. 10-11).

From an analysis of policy documents, mission statements and funding guidelines, it would appear that Jamaican donors have ignored such social divisions. Donors seemed to have overlooked, or have played down, the possibility of conflict over resource use between groups within a given area. It is apparent, from examination of policy documents, that donors presume a distinct homogenous 'community' exists (see EFJ, 1995b; Green Fund, 1995b; USAID, 1993). Peppered throughout their literature is reference to 'the community'. The Green Fund, for example, requests applicants to indicate how projects will, 'foster self-reliance in the community', and 'how they will have a multiplier effect in the community' (Green Fund, 1995b; my italics). Thus, despite a widespread recognition that social differences exist, simplistic notions of 'community' continue to inform bilateral and multilateral conservation aid programmes in Jamaica. As Leach et al. (1997, p. 11) point out, 'it is striking the degree to which simplistic notions of community are being reinvented in the context of practical efforts towards community-based sustainable development'. Equally misguided, as I will demonstrate shortly, is the assumption that environmental NGOs are representative of 'the community'.

\section{Jamaican ENGOs: representation and participation}

In the following sections I intend to discuss the social make-up of ENGOs and how community-based conservation policy has been put into practice. Using a variety of data sources, including a case study of the Portland Environmental Protection Association (PEPA), the paper raises a number of important concerns. These include, who do ENGOs actually represent and are they promoting 'community' participation?

\section{Representation and participation}

The research data is based on questionnaires distributed to a random sample of 16 out of the 36 Jamaican environmental NGOS. ${ }^{2}$ In addition, membership records were studied and interviews provided further information about the social class background of members which supports the questionnaire findings. As Table 1 below illustrates, the middle classes and well-educated were overwhelmingly more likely to be members of Jamaican ENGOs.

2. Approximately 857 questionnaires were distributed. In total 185 completed questionnaires were returned and analysed. 
Table 1 Social base/Jamaican environmental groups

\begin{tabular}{lc}
\hline Social class & $\%$ \\
\hline Social Class 1 & 12.4 \\
Social Class 2 & 51.4 \\
Social Class 3 & 10.8 \\
Social Class 4 & 1.1 \\
Social Class 5 & 0.0 \\
\hline
\end{tabular}

Note: Registrar General's Classification of Social Class applied.

As Table 1 indicates, almost $64 \%$ of the sample were from social classes 1 and 2 . Approximately $35 \%$ had completed higher level education. In contrast, in 1990, social classes 1 and 2 made up only $28 \%$ of the employed workforce in Jamaica (Economic and Social Survey, 1990). Gender and age were found not to be significant determinants of membership. Although these were slightly more female $(51.9 \%)$ than male members $(48.1 \%)$.

Regarding social class, it is clear from the research findings that the groups are not representative of the general population. Despite their limited social base, many environmental groups claim to be representative of 'the community'. Peppered throughout the campaign literature examined, there were statements from organisations claiming to, 'represent the parish' (PEPA, 1995); 'empower local communities' (CERC, 1995); 'act as a voice for community concerns' (STAEPA, 1994).

In addition to the unrepresentative nature of the groups, the research findings indicate that because volunteers and staff were usually drawn from the middle classes and better-off groups in society, they were frequently out of touch with the social circumstances in poorer communities. As the editorial in the NEST newsletter acknowledged, 'environmental organisations tend to be dominated by middle-class people, who, despite the very best of intentions, know very little about grass-root concerns' (NEST, 1994, p. 1).

However, it could be argued that, even though a group does not match the local population socially, it could still represent the interests of 'the local community' and act as an effective advocate on their behalf. The following case study of the Portland Environmental Protection Association (PEPA) explores this issue. PEPA was chosen on account of its high profile within the Jamaican environmental movement and because of its much publicised image as a successful community-based group. The case study illustrates, how local elites can come to dominate an organisation which claims to be 'community-based' and as a consequence may articulate their own concerns and interests. 


\section{Portland Environmental Protection Association: a case study}

PEPA was founded in 1988 by a group of concerned citizens in Port Antonio. According to campaign literature, PEPA is made up of representatives from 41 civic and citizens groups, and individuals (PEPA, 1995). This, it is argued, gives the organisation its mandate to represent the parish of Portland. PEPA is often cited as a model for other Jamaican ENGOs to emulate. As the Chairperson of NEST wrote, 'established and active NGOs like the Portland Environmental Protection Association (PEPA) have shown the way for newer groups to focus local concerns ...' (NEST, 1992b, p. 1). Or, as one PEPA activist puts it to me,

PEPA was the first environmental EPA in Jamaica. It's, if you like, the parent of all the EPAs. We are very much seen as the shining light, you know, the way forward.

Having observed several PEPA monthly meetings (held in one of the most exclusive hotels in Port Antonio), interviewed volunteers and paid staff, and attended a number of their organised events, it is clear that the organisation is overwhelmingly dominated by local professionals, business people, hoteliers and expatriates. As one PEPA member admitted,

The Board of Directors ... they are all in their own right powerful well established people. They can afford to be environmentally conscious. They have no conception of real life, they live in a cotton wool world, they really do. I despair sometimes when I hear them make statements because it disenfranchises large sections of the population (original emphasis).

Minutes from PEPA meetings, spanning over a period of five years, confirm that representatives from local community groups do occasionally attend the monthly meeting. However, the minutes also indicate that local business people and professionals predominate. They tend to direct proceedings and determine strategy. To describe this as community participation is questionable. From the research, it is clear that decision making has been captured by local elites. The following comment, from a PEPA member, reflect these sentiments.

It seems to me that what's happened is, over the years people have said, 'do you want to be part of PEPA', and they've said, 'yea its a good idea', and they've slapped their name on. They've not maintained a relationship. There is a bit of a loose relationship maintained because they get minutes of meetings, from the PEPA meetings. But ... I'm more and more convinced that what I'm actually involved in is a cosy little club.

As noted earlier, participation means more than occasional attendance at committee meetings or limited involvement in day-to-day activities and projects. It means more than simply being told what is happening. The PEPA case study casts doubt on the organisations representativeness and level of 
participation. Nevertheless, PEPA has received substantial funding from the Green Fund and EFJ for 'community-based' projects (EFJ, 1995c; Green Fund, 1995b; see footnote 3 for a list of projects funded). Amongst other things, EFJ has funded the production of a Board Game (Envirotrek) and an environmental seminar entitled 'The Greening of Portland's Hotels', aimed at local hotel owners. It is doubtful whether local communities played a significant role in the design and implementation of these projects. According to informants, the board game was the 'brainchild' of US Peace Corps volunteers. Indeed, based on observation and interviews, it is my contention that, much of PEPA's activities reflect the priorities of local elites. I would suggest that the Envirotrek board game is a case in point. Portland is one of the poorest parishes in Jamaica. It is unlikely that the production of a board game, which was awarded JA $\$ 747,267$ by EFJ (EFJ, 1995c), reflects the interests of the majority in Portland's poorest communities struggling to make ends meet.

\section{Implications for policy and practice}

The above discussion raises a number of important issues. Firstly, foreign donors do not appear to have vigorously scrutinised the mandate of environmental groups. Instead they have channelled the bulk of aid for 'community-based' conservation projects through, what can only be described as, elite organisations. It is apparent that in order to legitimate projects, and to meet funding requirements set by international donors, some ENGOs have 'overstated' the level and type of participation in their organisation and projects. Donors seem to assume participation is taking place because a handful of individuals claim to be representative. ${ }^{4}$

Secondly, issues of participation and representation raise questions about the equitable allocation of funding. Middle class environmental groups are not problematic in themselves. However, problems arise when elite groups claim to represent 'the community' and access funding on their behalf. The research indicates that many Jamaican environmental groups represent the concerns and priorities of a narrow constituency. The concerns and interests

3. The following is a list of PEPA projects funded by (a) EFJ and (b) the Green Fund. (a) 1993, Envirotrek Board Game; 1994, Attendance at Second Global Conference; 1994, Environmental Workshop, Portland/St Thomas; 1995, Pep Clubs, Environmental Awareness Schools Programme; 1995 , Greening of Portland's Hotels. (b) July 1993-March 1995, Adult Environmental Outreach Programme; Support for attendance at The Nature Conservancy (TNC) Board Meeting (TNC is a Washington based environmental organisation). PEPA had no written reports on the above projects. The organisation did not produce an annual report. A number of the projects did involve work with local schools and communities. Notwithstanding this, the point I am stressing is that PEPA has not generated community participation, as defined by Cernea( 1985), and discussed above. Instead, there is evidence to suggest that, local people are treated as passive beneficiaries. Defining this as community participation is problematic.

4. EFJ and Green Fund project funding application forms have specific sections which require applicants to describe the type and extent of community participation in their group and proposed project. EFJ request that letters of endorsement are attached to proposals as 'proof' of community support for projects. However, it is likely that groups could show, at least on paper, that they have support of community groups etc. 
of poorer and marginalised groups, those often without a voice, are often excluded from the process. Poor and marginalised groups are unlikely to have the resources to organise themselves and so successfully access funding. Thus, 'participation', as practised by ENGOs in Jamaica, has important shortcomings. That is, it may be unintentionally reinforcing unequal social relations, as opposed to empowering or giving a voice to marginalised groups. It is my contention that this issue could be taken one step further. Are conservation projects creating or reinforcing social inequalities and conflict within, or between, towns and villages? This is an important issue which requires further research. ${ }^{5}$

Thirdly, issues of representation and lack of participation, undermine the fundamental policy objectives of generating 'local-level solutions', derived from, 'community based' initiatives; and, Principle 10 of the Rio Declaration, which states that, 'each individual shall have appropriate access to information concerning the environment ... including information on ... activities in their communities, and the opportunity to participate in decision-making processes' (United Nations, 1992). The 'solutions' being put forward, and the projects that are funded, have in general not been generated by 'the community'. Past experience and research has shown that without genuine involvement of local people, projects are likely to fail (see, for example, Leach et al., 1997; Pimbert and Pretty, 1995). Pimbert and Pretty (1995) have argued that it is when local people are excluded that degradation is more likely to occur. Ironically, those more likely to be effected by environmental degradation (the poor and marginalised), are the least likely to be involved in 'community-based' conservation projects in Jamaica. It is difficult not to conclude that international donors have learnt nothing from past mistakes. As noted earlier, practitioners and policy makers should address these failures, and endeavour to understand the impediments to community participation, in order to make appropriate changes and adjustments to programmes.

\section{Conclusion}

This paper raises a number of important issues for policy makers, practitioners and future research. The unrepresentative nature of Jamaican ENGOs was identified as a key constraint on achieving policy objectives and initiating genuine community based initiatives. It was suggested that donors need to ensure that community-based environmental projects reflect a broader representation of the diversity of local interests and concerns, not just the interests of a select few. As noted earlier, simplistic notions of 'community' continue to inform bilateral and multilateral conservation aid programmes in Jamaica. A further issue of concern which the paper raised is

5. The author is currently in the process of applying for funding to study the social impact of conservation projects in Jamaica. 
whether or not projects are creating social inequalities and conflict. As discussed earlier, specific social groups and areas may stand to win or lose from conservation schemes. It is apparent that the social impact of conservation projects in Jamaica has so far been little researched. The overall conclusion of the paper is that huge contradiction exist between community-based conservation policy and practice. Many of the problems identified in this paper are, however, not new. Indeed, there is a striking similarity in accounts of problems in community development projects in the past and present conservation projects.

Patricia Lundy is a lecturer in Sociology with the University of Ulster.

Address for correspondence: University of Ulster, Magee College, Northland Road, Derry, Northern Ireland. email: p.lundy@ulst.ac.uk

\section{Acknowledgement}

Funding for this paper was received from the British Academy and the Nuffield Foundation.

\section{Bibliography}

Bebbington, A. and Thiele, G. (eds), (1993), NGOs and the State in Latin America: Rethinking Roles in Sustainable Agricultural Development, Routledge, London.

Carroll, T., (1992), Intermediary NGOs; the Supporting Link in Grassroots Development, Kumarian Press, West Hartford.

Cernea, M. (ed.), (1985), Putting People First: Sociological Variables in Rural Development, Oxford University Press, New York.

Clark, J., (1997), 'The state, popular participation and the voluntary sector', in Hulme, D. and Edwards, M. (eds), NGOs, States and Donors: Too Close for Comfort, Macmillan, Basingstoke.

Cohen, A., (1985), The Symbolic Construction of Community, Routledge, London.

Community Environmental Resource Centre (CERC), (1995), 'Harbour View Weekend Grand Market', Funding Application, Caribbean Cement Company, 5-6 August.

Croft, S. and Beresford, P., (1992), 'The Politics of Participation', Critical Social Policy, 35, pp. 20-44.

Edwards, M. and Hulme, D., (1995), Non-Governmental Organisations - Performance and Accountability: Beyond the Magic Bullet, Earthscan.

Environmental Foundation of Jamaica (EFJ), (1995a), Information Leaflet, Kingston, Jamaica.

Environmental Foundation of Jamaica (EFJ), (1995b), Guidelines for Requesting Funding Assistance From the EFJ, Kingston, Jamaica.

Environmental Foundation of Jamaica (EFJ), (1995c), Environmental and Related Projects, Kingston, Jamaica.

Green Fund, (1995a), Canada/Jamaica Green Fund Project Information Leaflet, Kingston, Jamaica. 
Green Fund, (1995b), Canada/Jamaica Green Fund, Document no. 504/18107, Annex A, CIDA.

Leach, M. et al., (1997), Environmental Entitlements: A Framework for Understanding the Institutional Dynamics of Environmental Change, Discussion Paper, IDS, University of Sussex.

Lundy, P., (1998), 'Fragmented community action or new social movement? A study of environmentalism in Jamaica', International Sociology, 14, 96-116.

Moore, D. S., (1993), 'Contested terrain in Zimbabwe's Eastern Highlands: political ecology, ethnography and peasant resource struggles', Economic Geography, 69(4): $380-401$.

National Environmental Societies Trust (NEST), (1991), Living in Harmony with Nature, Information Booklet, Kingston, Jamaica.

National Environmental Societies Trust (NEST), (1992a), Chirpings, NEST Newsletter, July, Kingston, Jamaica.

National Environmental Societies Trust (NEST), (1992b), Annual Report, Kingston, Jamaica.

National Environmental Societies Trust (NEST), (1994a), Chirpings, NEST Newsletter, March/April.

National Environmental Societies Trust (NEST), (1994b), Chirpings, NEST Newsletter, September/October.

National Environmental Societies Trust (NEST), (1995), Jamaican ENGOs and the State: The Co-management Option, Discussion Paper presented at the 3rd National Quarterly ENGO Forum, 2-3 September, Bluefields, Jamaica.

Pimbert, M. and Pretty, J., (1995), Parks People and Professionals: Putting Participation into Protected Area Management, UNRISD Discussion Paper No. 57.

Portland Environmental Protection Association (PEPA), (1995), Information Leaflet, Portland, Jamaica.

Rahnema, M., (1992), 'Participation', in Sachs, W. (ed), The Development Dictionary, Zed Books, London.

Riddell, R. and Robinson, M., (1992), The Impact of NGO Poverty Alleviation Projects: Results of the Case Study Evaluations, Working Paper No. 68, Overseas Development Institute, London.

Shortall, S., (1994), 'The Irish rural development paradigm - an exploratory analysis', The Economic and Social Review, 25(3), 233-260.

Shah, P. and Shah, M. R., (1995), 'Participatory methods for increasing NGO accountability: a case study from India', in Edwards, D. and Hulme, ?., NonGovernmental Organisations - Performance and Accountability: Beyond the Magic Bullet, Earthscan, London.

STAEPA, (1994), St. Ann Environment Protection Association, Information Leaflet.

United Nations, (1992), Report of the United Nations Conference on Environment and Development, UNCED Report A/CONF, 151/Rev. 1, 13 June.

USAID, (1993), Development of Environmental Management Organisations, PARC II - Component - Project Paper Supplement, Project No. 532-0173, USAID, Jamaica.

Vivian, J., (1994), 'NGOs and sustainable development in Zimbabwe: no magic bullets', Development and Change, 25, 181-209. 